\title{
PROMOTING LOCAL POTENTIAL AS A STRATEGY TO DEVELOP TOURISM VILLAGE
}

\author{
ISTIQOMAH \\ Universitas Jenderal Soedirman, Faculty of Economics and Business, Indonesia, e-mail: istiqomahsubechan@ gmail.com \\ Wiwiek Rabiatul ADAWIYAH* \\ Universitas Jenderal Soedirman, Faculty of Economics and Business, Indonesia, e-mail: wiwiek.adawiyah@unsoed.ac.id \\ Agung PRAPTAPA \\ Universitas Jenderal Soedirman, Faculty of Economics and Business, Indonesia, e-mail: agung.praptapa@unsoed.ac.id \\ Poppy Dian Indira KUSUMA \\ Universitas Jenderal Soedirman, Faculty of Economics and Business, Indonesia, e-mail: poppy.kusuma@unsoed.ac.id
}

Zahrotush SHOLIKHAH

Universitas Negeri Yogyakarta, Faculty of Economics, Indonesia, e-mail: zahrotush.s@uny.ac.id

Citation: Istiqomah, Adawiyah, W.R., Praptapa, A., Kusuma, P.D.I, \& Sholikhah, Z. (2020). PROMOTING LOCAL POTENTIAL AS A STRATEGY TO DEVELOP TOURISM VILLAGE. GeoJournal of Tourism and Geosites, 31(3), 1113-1118. https://doi.org/10.30892/gtg.31324-547

\begin{abstract}
The development of tourism significantly contributes to the nation's economic growth, but it involves a trade-off between ecosystem services and social and cultural identities in many developing countries. Tourism village should preserve the local customs, safeguarding the environment and having a positive impact on its surroundings. The village of Papringan has several peculiarities: local food, traditional arts and nature's attractions such as waterfalls, therefore deserves to be marketed as a tourism destination packaging. The competitiveness of the tourist village is also inseparable from the government's role in providing the community with excellent, full services and active participation. This study seeks to establish a strategy for the establishment of the village of Papringan tourism, based on local wisdom. A series of semi-structured interviews were conducted with village officials, batik artists, local artisans and civic leaders. The information collected is grouped into four SWOT categories using content analysis. The goal the analysis is to recognize strengths, weaknesses, opportunities and challenges faced by the village authority while developing Papringan as tourism village. Theoretically, the result of this stud provides a new insight in the field of tourism village development. At the practical level, our findings can be used as a reference by the local authority in providing resolution of community problems, particularly those related to the tourism strategy in the Banyumas Regency villages. The success of making Papringan a tourist village shall have a multiplier effect in the form of higher rural communities' welfare, increased revenue from tourism sector; infra-structure betterment to increase tourist access.
\end{abstract}

Keywords: rural destination object, local wisdom, local entrepreneurial supports, development strategy

$* \quad * \quad * \quad * \quad * *$

\section{INTRODUCTION}

The role of the tourism sector in fostering economic development in the rural area is an important research strand. The economic literature has essentially shifted from merely informative to a more comprehensive understanding of rural areas' growth conditions. The tourism sector's role is vital in the Indonesian economy. Tourism accounted for 9.3\% of the Gross National Product (GDP) in 2014, 8.4\% for domestic employment and creating 9.8 million jobs. Approximately 15,18 million foreign tourists, visited Indonesia exchanged 16,7 billion USD in 2019. Despite the astonishing figure, the foreign tourist spending in Malaysia and Thailand is slightly higher, around $\$ 1.100$ per person (Ministry of Tourism and Creative Economy Indonesia, 2019). Considering the tourism sector potential, the Indonesian government has attempted to prioritize tourism as an alternative source of revenue for rural development. The unique cultural heritage and nature are some of the comparative benefits of Indonesia's tourism village, which possibly attracts a significant number of visitors every year.

Rural areas have strong potential due to their unique natural resources and cultural wisdom. The idiosyncratic social legacy and ecological haunt are a part of the rural tourism focal points which have attracted a substantial number of visitors (Grilli et al., 2020). The travel industry's likely commitment to economic development and business age and the restricted open doors to economic expansion have made the networks of the tourist industry the best way of enhancing the travel sector. However, the country regions and lifestyle in the province (Gao and Wu, 2017) have suffered a global emergency since late in times of urbanization and modernization, in particular in the creation of nations and rustic culture. The Culture and Tourism Minister proposed the national empowerment program (PNPM) for tourism destinations in 2014. One hundred four tourist villages in Indonesia are being developed by the Ministry of Culture and Tourism (Adawiyah et al., 2015).

Rural tourism can have a positive influence on the socio-cultural environment through the host-visitors' interaction. A comprehensive national development needs to be carried out to promote the sector as a way to increase the well-being of those who live in rural areas. In many developing countries, rural tourism is tied up with development plans (Briedenhann and Wickens, 2004; Gannon, 1994; Wihuda et al., 2017). Rural tourism is classified as a small business because of its unique nature (Bramwell, 1994). The customs and en vironmental protection of tourism and their genuine positive impact on tourist attractions should be upheld by tourism in the community (Adi et al., 2017; Hari Adi and Adawiyah, 2018; Sharpley and Roberts, 2004).

The competitiveness of the tourist village is also inseparable from the government's interventions (Perales, 2002). The local authority must accelerate the tourism development in the rural area. Efforts have been advocated by the Indonesian government policy to promote the sustainability of the tourism industry in the countryside. Sustainable tourism policies can, in turn, generate jobs and alleviate suffering. 
Consequently, tourist village should be seen as an opportunity to increase rural economic growth, while at the same time protecting biodiversity and promoting and maintaining local culture. However, there are several hurdles to a policy aimed at promoting more sustainability in tourism and complicated economic, environmental and social policy compromise. To support the initiation and development of the tourist village, the Indonesian government needs financial assistance which can be obtained from private investments. For this reason, information about the existence and extent of values of Papringan village as a potential tourist object is required in order to form positive preferences of potential prospective tourists. The unique lifestyle, handcraft and typical village art are potential features to be offered as a valuable attraction to tourists.

Research on rural tourism village development in remote areas has been limited in Indonesia. This paper aims to develop a strategy for developing Papringan village as a potential tourism object. The village of Papringan is located in the south of the river Serayu Banyumas regency, Central Java Indonesia. The river of Serayu is situated in the rhythm of the village. The Papringan village is famous of its Banyumasan batik craft, a majority of the women do batik work such as design patterns, tinting, colouring and timing to enjoy time to help increase family income (Istiqomah and Adawiyah, 2018). Batik was transmitted to the rhythm of rural Banyumas through generations. Figure 1 shows the village's geographical position.

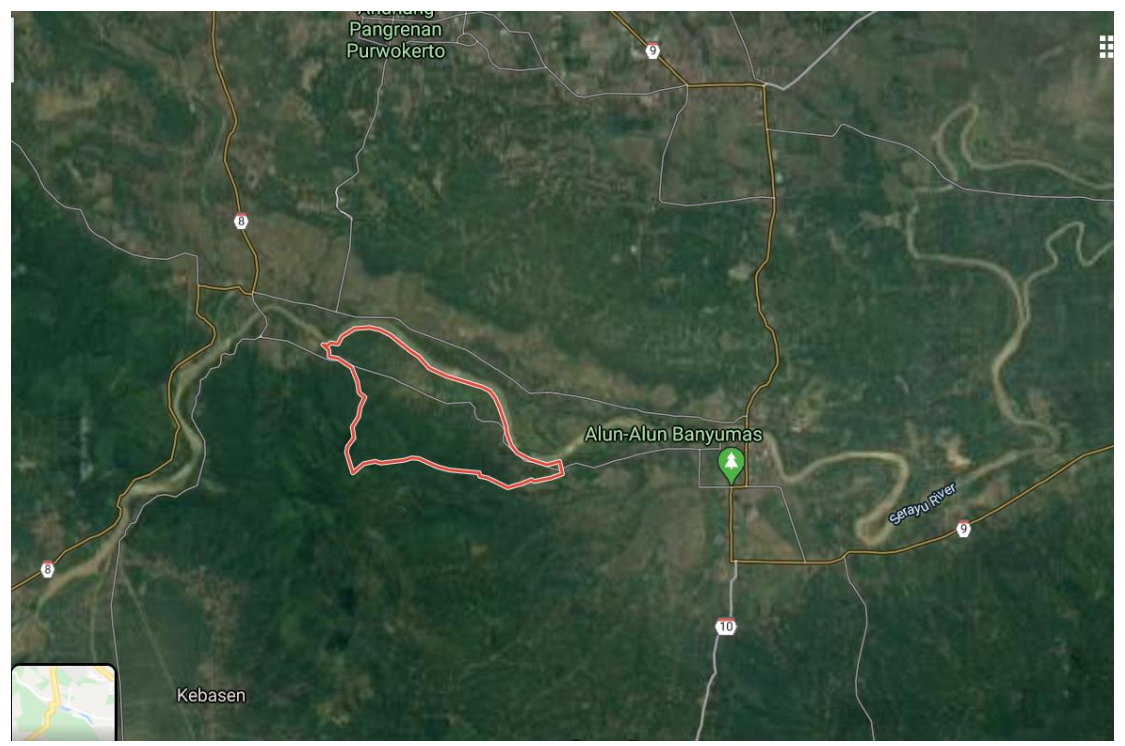

Figure 1. The geographical location of the tourism village (Source: Google Map)

There are many tourist potential areas within the village of Papringan including the Serayu River and Turgid Krucuk water sources near the old town of Banyumas, the Banyumasan lengger, Nyadran, Cowongan, Sedekah Bumi and the Calung Banyumasan music. The potentials of the old city of Banyumas, the ancient mosque in the village of Papringan, the Dawuhan cemetery for Banyumas pioneering figure, all can be simultaneously developed. The village of Papringan is not yet famous as the home of Banyumasan batik. There is a batik-pressing gallery on the site. Infrastructure is not well maintained, and the natural environment has not yet been developed optimally. The public has also not received a right touch from the local government concerning the natural beauty and potentials of the village.

The villagers must always preserve their traditions and cultures. The Batik motif is used to implement the traditions, environment and nature of Papringan Village. Banyumas' greatness was shown in the motive of jagatan once in the past civilization. Punakawan, Bawor or Bagong, is a symbol of affliction and innocence. Batik craftsmanship is not the artisan's primary source of revenue. The lack of a group or partnership formed by the Regional Government makes the Papringan batik less competitive than batik from other towns (Pinasti and Adawiyah, 201).

Advancing the Papringan Batik Center requires the synergizing efforts of various parties, including academics and banks. The lack of qualified human resources leads to the lack of rapid progress in the batik papringan gallery, like other batik galleries. At trade fairs in several countries such as England, Japan, Hong Kong, and India, the Batik products of Papringan were displayed. The objective of this study is to succeed the Government Program in order to realize the tourist village, by examining the variety of potentials of the village of Papringan and identifying opportunities and limitations.

\section{LITERATURE REVIEW}

\section{Competitive Strategy}

Strategic management describes both a mechanism and a technique to address the strategic difficulties of an organization (Noe et al., 2006). It is seen as a management pattern or strategy implemented sequentially into a whole organization with critical goals, policies and actions of the company. There are four indicators of valuable and rare skills among existing companies and potential competitors, ineligibility or non-replacement that can be a source of sustainable competitive advantage. Tourism in the country and periphery is facing many challenges because people do not know what the preservation of rural heritage is (Ghaderi and Henderson, 2012; Grilli et al., 2020). In order to maintain a valuable heritage, substantial expenditure in human capital in ways such as informal education and tra ining with academics is beneficial. In addition, people need to be more informed of the importance of protecting the natural ecosystem, through religious norms (Adawiyah and Pramuka, 2017; Hari Adi and Adawiyah, 2018).

The Pringmas Group in the village of Papringan represents one of the reliable tourism potentials in Banyumas regency. The efforts to develop the group are through various educational and training programs to develop human resources. Training on general aspects, such as basic entrepreneurial understanding, essential management and marketing, business planning development has been carried out. Entrepreneurial training provides future entrepreneurs with the knowledge and skills needed to anticipate rapid business changes (Honig, 2004). Special training is also available, such as production costs optimization, employee incentive determination strategies, and financial budgeting (Adawiyah, 2015). Human resource development is defined by the preparation, to the development of standards, knowledge, attitudes, skills or responsibilities for individuals or groups with a set of information and knowledge. Human development characteristics are designed to meet future needs, are long-term and anticipated changes. Education is a deliberate attempt to change the 
knowledge, attitudes and skills of an individual constructively to prepare entrepreneurs and managers with the skills to face challenges (Dickson et al., 2008). Training, however, is a planned endeavour, following the business's scale, to improve one type or more specific qualifications. Upon the accomplishment of training, one is expected the exhibit a new behaviour resulting in the escalation of productivity, higher discipline, a favourable attitude and higher level of skill and expertise (Pretorius et al., 2005; Putri et al., 2017). The training is, therefore, currently oriented towards the needs, and the results are more measurable and situational.

\section{Tourist Object Competitiveness}

Lack of competitiveness means that an object has no reason for surviving (Abeson and Taku, 2009). Competitiveness depends on how effective a business entity in offering their product or service on the competitive market (López et al., 2011). Competition is at the heart of successful management of tourist destinations. The competitiveness of tourism destination is a multidimensional term widely discussed in academic literature. The rigorous scientific literature accepts that, because of the effect of many variables or dimensions affecting the performance of a destination, it is difficult for the definition of tourism competitiveness to be defined and decided (Croes, 2011; Fernández et al., 2020). Many studies tried to recognize and assess these factors. However, there was no widespread agreement as to how the competitiveness of tourism was described. In the last decades, there has been a substantial growth of initiatives addressing the need for tracking the competitiveness of tourist destinations, with various suggestions to identify and calculate their competitiveness (Martín et al., 2017; Mazanec and Ring, 2011). There is an ongoing debate about the need to screen the seriousness of tourist objects with various degree of intensity (Fernández et al., 2020; Mazanec et al., 2007). The objective is to assess the travel industry competitiveness, since such estimation can add to organizing the activities arranged and the assets apportioned to profit the part (Barbosa et al., 2010). The level of competitiveness of a tourism object can be measured in several manners including a quantitative point of view through an examination of information from multiple sources such as vacationers, the travel industry specialists (Fernández et al., 2020).

\section{MATERIALS AND METHODS}

The study employed a qualitative approach with a case study (Yin, 2009). The qualitative study describes the social development parts of the real world. The subjective exploration techniques try to reveal the socio-social significance and experience of the subject of examination on a non-numeric marvel (Denzin and Lincoln, 2017). Authors adopted triangulation techniques to ensure the validity and reliability of the information obtained during the study (Miles et al., 2013). In the meantime, case studies are transforming perceptions into useful information, offering indiscriminate information from direct perceptions of the individual element (Yin, 2009). These perceptions provide information on forms of information. Since the information is produced gradually, the case study procedure also identifies a specific incident inside and outside regarding the way the viewers can improve it, which gives them additional credibility. The strategy of contextual analys is includes something different from interviews and direct perception. With this strategy, case chronicles from the database can be used.

This investigation took place in the village of Papringan in Banyumas Central Java, Indonesia. The techniques used to collect data in this study include observation, in-depth interviews and focus group debates. Snowball was the sampling method. There were ten researchers in the village councils, batik artisans, artists and community leaders. Semi-structured interviews have collected data to identify the perception by informants of internal or external factors that can influence the initiation of rural community tourism in the village of Papringan, Banyuma district. A semi-structured interview with the local authority, batikers, local artists and community leaders were conducted. The analysis of data was carried out using a method of interaction that emphasized the relation of the three main components: data reduction, data presentation and the drawing of verification/conclusion (Miles et al., 2013). In order to classify variables into four set categories, the information is transcribed and analyzed using content analysis. The goal of SWOT analysis is to identify the strengths, weaknesses, options and threats. Likewise, the findings of this study provide an understanding at the community level of tourism governance. In the next stage, the authors also identified possible obstacles and factors that support the village of tourism. Data were collected with open questionnaires and then descriptively analyzed.

\section{RESULTS DISCUSSIONS}

Description of informants

The success of realizing Papringan into a tourism village will have a positive impact such as 1) increasing the welfare of rural communities; 2) increase regional tourism income; 3) increase the infrastructure supporting tourism villages; 4) increase other parties as well as learn acceptable practices on villages of tourism. The results of the study also help to map tourism, anticipate restrictions and develop strategies to establish a tourist village in Papringan. Some of the strength of the villages were attributed to their local potentials such as natural views -waterfalls, river banks- arts, traditional wears and many more. Meanwhile among the drawbacks were limited human resources knowledge and skills in managing the village. Table 1 presents the SWOT analysis of local wisdom-based tourism.

\section{Supporting and Inhibiting Factors for Business Success in the Village}

Besides being influenced by internal factors such as business characteristics, development of tourism village is also influenced by external factors. These external factors include:

1. Accessibility. This aspect is related to access to roads, the internet, clean water and electricity. Most of the internet facilities are located in cities and often do not reach rural areas or even remote areas. This limited internet access can be an obstacle, e specially in the current era, where the competition for marketing right products and services is already internet-based. Other obstacles and challenges of rural tourism are limited vision or clear perception of the community about tourism, low interest and public awareness, low human resource capabilities in technology deployment, cultural barriers (cultural barriers), coercion and deception of tourists.

2. Distance. Furthermore, distance can also affect the interests of tourist to visit rural areas. The quality of in frastructure in the village is an essential consideration for tourist decision whether or not to visit the location. The result of interviews with the stakeholders revealed the need for developing a public transportation hub, to attract more local land foreign visitors.

3. Networking. To promote the village potential, the local government should establish a good partnership with their neighbourhood. The villagers who migrated to the urban area may act as an agent of change by establishing a strategic alliance with tourists' community. The ability to build networks with foreign parties, both consumers, producers, and the government, is one of the critical factors in increasing the performance of the tourism village. 
4. Local tourism support organizations (LTSOs) is a forum that aims to accelerate the realization of independent entrepreneurs who provide services in the form of business incubation, information services and business consulting, initiation of network form ation, and various kinds of entrepreneurial awareness programs. TSOs are elements consisting of village governments, community leaders and youth in rural areas. Figure 2 illustrates LTSOs as follows.

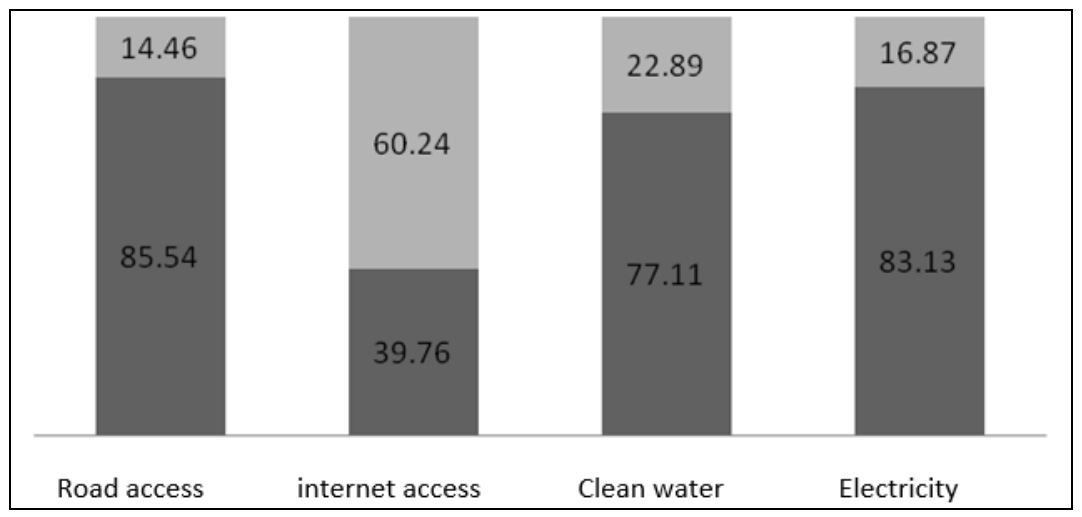

Figure 2. Inhibiting factors for tourism village development

\section{Strength, Weaknesses, Opportunity and Threat Analysis}

SWOT stands for Strength, Weakness, Opportunities, and Threats, which systematically help an organization to identify external factors $(\mathrm{O}$ and $\mathrm{T})$ as well as factors within the company ( $\mathrm{S}$ and $\mathrm{W})$. SWOT is used to formulate a mature plan to achieve organizational goals both in the short and long term. In this study, we use strategy formulation by combining the SWOT components. To formulate the short term strategy, the authors analyze the possible combination of opportunities and strengths ( $\mathrm{O}$ and $\mathrm{S})$. We have added three strategies to empower the village's strength in seizing the opportunities in the market: first, cooperate with the experts to identify the villages potential that can be upsurge into valuable attractions; second, cooperate with the local authority to improve infrastructure especially road access to the location; and conduct training for small business in the villages to improve the quality of their products.

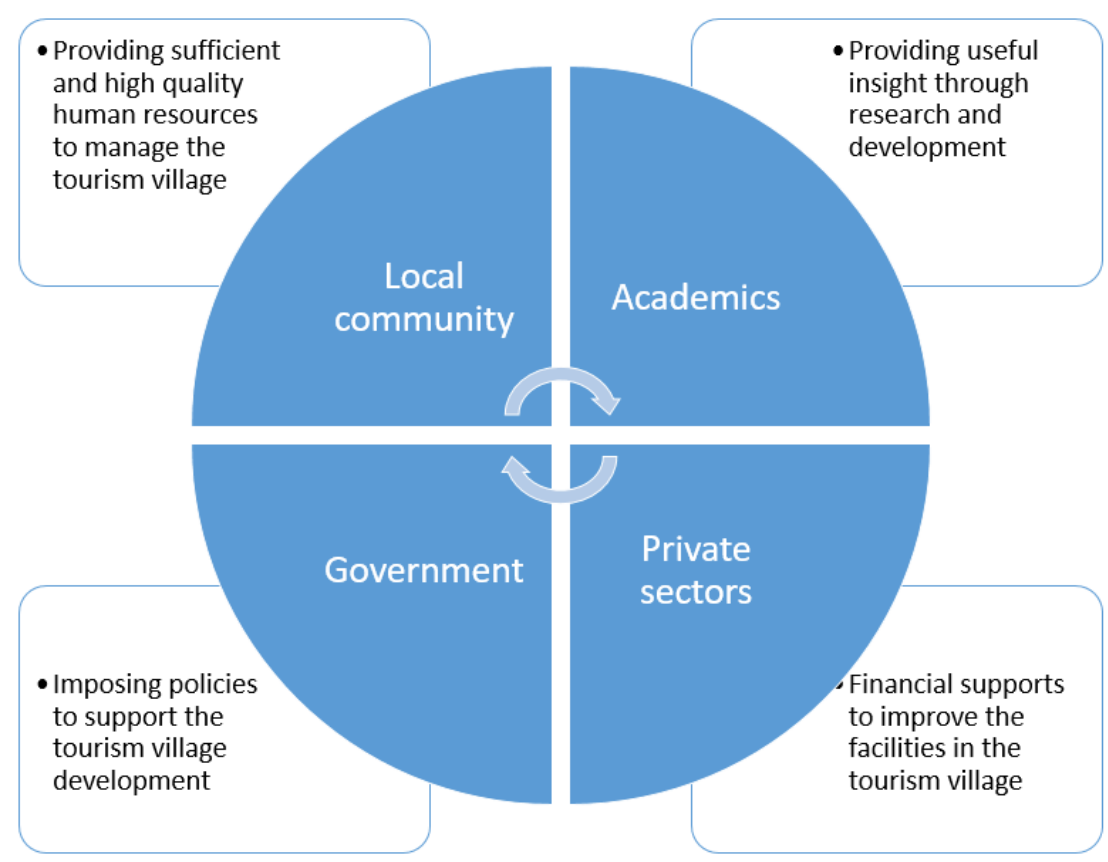

Figure 3. Local support system for the Batik Tourism Village

(Source: Primary data obtained using open questionnaires and in-depth interview)

SWOT analysis allows an organization to formulate the core strategy as an advanced stage of implementation of organizational objectives. The results of the analysis can also lead to a change in mission, objectives, policies, or an ongoing strategy-preliminary knowledge on the availability of resources and funds before launching the village as a tourist object. Internal factors, strength and weaknesses, play a potential role in executing the business plan. On the other hand, it is also necessary to pay attention to the external factors, the opportunities that may arise to address threats that will affect the tourism village. We have developed three strategies in this case. One way to take the opportunity of the tourism market is by increase cooperation with various parties in promoting the village. The local authority may utilize various media forms to introduce the village to a potential tourist.

Moreover, the village leaders can use marketing gimmick at the initial stage of promotion and offer a bonus to travel agents every time they take visitors to the location. Establish networking through various parties such as local people who work in other cities also endeavoured. Maximizing promotion through social media such as Facebook, Instagram, and Twitter are among the efficient way of promoting the village. Detailed of the strategies are depicted in table 1. 
Table 1. SWOT analysis of local wisdom-based tourism

\begin{tabular}{|c|c|c|c|}
\hline \multicolumn{3}{|l|}{ Internal Factor } & WEAKNESS (W) \\
\hline \multicolumn{2}{|c|}{ External Factor } & $\begin{array}{ll}\text { 1. } & \text { Village arts such as traditional dance and } \\
\text { 2. Javanese Gamelan (local wisdom music) } \\
\text { Distinctive motifs for batik design such as } \\
\text { Pringsedapur } \\
\text { 3. Strategic location, close to river banks } \\
\text { 4. Potential for eco-tourism such as waterfalls } \\
\text { 5. Increase variation of the regional specialities such } \\
\text { as crackers from cassava and local fruits. }\end{array}$ & $\begin{array}{l}\text { 1. No patents/ copyrights on the motifs } \\
\text { 2. Small water debit for the waterfall } \\
\text { during the dry season } \\
\text { 3. Absence of regulation to protect } \\
\text { tourists' security and safety } \\
\text { 4. Scarcity of funds to support the } \\
\text { development of the tourism village } \\
\text { 5. Lack of interest among the youngsters to } \\
\text { inherit the batik crafting skills. }\end{array}$ \\
\hline $\begin{array}{l}\text { OPPORTUNITY } \\
(\mathrm{O})\end{array}$ & $\begin{array}{l}\text { Team up with } \\
\text { academics, local } \\
\text { authorities and private } \\
\text { companies for the } \\
\text { development of tourism } \\
\text { villages. }\end{array}$ & $\begin{array}{l}\text { S-O Strategies } \\
\text { 1. Magnify cooperation with academics to identify } \\
\text { the village's market potential } \\
\text { 2. Improve infrastructure in collaboration with the } \\
\text { regional government } \\
\text { 3. Cooperate with the academics and ministry of } \\
\text { Agriculture to improve the local food quality. }\end{array}$ & $\begin{array}{l}\text { W-O Strategies } \\
\text { 1. Seek advice from the regional authority } \\
\text { to protect their indigenous motifs. } \\
\text { 2. Cooperate with the local governments } \\
\text { to preserve waterfall discharge. } \\
\text { 3. } \begin{array}{l}\text { Proactively search for potential } \\
\text { investors to finance the development in } \\
\text { the region based on the priority. }\end{array}\end{array}$ \\
\hline THREAT (T) & $\begin{array}{l}\text { The presence of existing } \\
\text { competitors around the } \\
\text { village that offer similar } \\
\text { or even more attractive } \\
\text { and well-established } \\
\text { tourism objects/ } \\
\text { location }\end{array}$ & $\begin{array}{l}\text { S-T Strategies } \\
\text { 1. } \\
\text { Cooperate with the local governments and } \\
\text { academia to promote the village as a tourist } \\
\text { destination } \\
\text { 2. } \begin{array}{l}\text { Establish networking through various parties such } \\
\text { as local people who work in other cities and } \\
\text { travel agents in Indonesia. } \\
\text { They are maximizing promotion through social } \\
\text { media such as Facebook, Instagram and Twitter. }\end{array}\end{array}$ & $\begin{array}{l}\text { W-T Strategies } \\
\text { 1. Improve product packaging and protect } \\
\text { their unique resources with copyright. } \\
\text { 2. Systematically educate the youngsters on } \\
\text { the importance of preserving their } \\
\text { cultural heritage. } \\
\text { 3. Improve the marketing systems to make } \\
\text { the tourist object economically feasible }\end{array}$ \\
\hline
\end{tabular}

STRATEGIC PLAN

Seek experts' advice from universities and local governments to identify tourism potential in the village. Implement the "blue ocean strategy" to increase the competitiveness of Papringan village as a new tourist object.

\section{CONCLUSION}

This study aims to formulate a tourism village development strategy as a way to spur economic growth while conserving the environment. In their attempt to promote their region as a tourists' object, the people of Papringan village still encounter several obstacles, including lack of young generation as they think thank to generate a quality idea. Majority of the youngsters prefer to work in some big cities, rather than working in the countryside. Second, lack of agreed standards on some of the products offered, such as variations in the colouring skills of batik artisan, has lower the quality of the goods. Third, a small business producing local foods relies on agricultural products produced in the area which affect the availability of raw materials used for production. With open market systems, consumers prefer high-quality products, regardless of their origin. The rural resources are unable to compete with urban resources. The application of patterns of mass tourism development, which affect the environment, is often incorrectly carried out in rural areas. The tourism sector is a sector in which villagers have relied upon to improve their economic situation. Promoting rural tourism will not only improve local economic welfare but will also increase the socio-cultural value and preservation of the environment. Natural tourism, agri-tourism, cultural tourism, creative tourism and adventure tourism with strong rural roots include objects of rural tourism. The results of that study are useful information to speed up economic development in rural areas, a national issue for which different parties, including academics, need to address themselves immediately.

\section{IMPLICATION}

Our research results are expected to provide a better understanding of how to manage the tourism sector in rural areas. Although our analysis is based on a case study in Papringan village, the study recommendations can be generalized, offering useful insights for rural tourism development in other regions. At the same time, the resulting strategy also provides a relatively detailed explanation of the roles of stakeholders in managing rural tourism. Overall, the results of this empirical research can be used as benchmarks in managing various types of rural tourism projects through more robust, sustainable rural tourism cooperation networks. Our project results also demonstrate the need to raise awareness of the importance of local natural and cultural capital in Indonesia. To overcome the limited capital of tourism village managers, it is necessary to build a network of cooperation with formal financial institutions and carry out promotions to both domestic and foreign investors. Another alternative is to provide opportunities for lar ge companies to channel a small portion of their funds for tourism development in rural areas, as a form of social care. To reduce the effects of environmental damage due to the high number of tourist visits, tourism village managers can promote environmentally friendly promotions such as not littering, not stepping on grass and using water as needed. At the practical level, the results of this study can be used as a reference by the local authority in developing rural tourism in the Banyumas district.

Moreover, the strategy developed in this study can overcome the scant of operational guidelines for policymaker in Banyumas Regency can especially for developing small businesses as the complementary factor for tourism village. We are also contributing to the pieces of literature of rural tourism by providing additional information based on a case study in Papriangan village. The government should find the best way to motivate the villagers so that they voluntarily participate in the project.

\section{Acknowledgements}

This research is not possible without the support of various parties. We, therefore, would like to express our gratitude to the management of Universitas Jenderal Soedirman for providing financial supports for this project. 


\section{REFERENCES}

Abeson, F., \& Taku, M.A. (2009). Knowledge source and small business competitiveness. Competitiveness Review, International Business Journal, 19(2), 8895. https://doi.org/10.1108/10595420910942252

Adawiyah, W. (2015). Impression management tactics, work-related behaviour and perceived individual performance of sales clerks: a case of Indonesia. International Journal of Applied Business and Economic Research, 13(7), 5481-5501.

Adawiyah, W.R., \& Pramuka, B.A. (2017). Scaling the notion of Islamic spirituality in the workplace. Journal of Management Development, 36(7), 877-898. https://doi.org/10.1108/JMD-11-2014-0153

Adawiyah, W.R., Pramuka, B.A., Najmudin, \& Jati, D.P. (2015). Green Supply Chain Management and its Impact on Construction Sector Small and Medium Enterprises (SMEs) Performance: A Case of Indonesia. International Business Management, 9(6), 1010-1024.

Adi, P.H., Wihuda, F., \& Adawiyah, W.R. (2017). The role of social media browsing intention for behavioral outcomes of young consumers. Trziste - Market, 29(1), 39. https://doi.org/10.22598/mt/2017.29.1.39

Barbosa, L.G.M., Oliveira, C.T.F. d., \& Rezende, C. (2010). Competitiveness of tourist destinations: the study of 65 key destinations for the development of regional tourism. Revista de Administração Pública, 44(5), 1067-1095. https://doi.org/10.1590/S0034-76122010000500004

Bramwell, B. (1994). Rural tourism and sustainable rural tourism. Journal of Sustainable Tourism, 2(1-2), 1-6. https://doi.org/10.1080/09669589409510679

Briedenhann, J., \& Wickens, E. (2004). Rural tourism-meeting the challenges of the new South Africa. International Journal of Tourism Research, 6(3), 189203. https://doi.org/10.1002/jtr.484

Croes, R. (2011). Measuring and Explaining Competitiveness in the Context of Small Island Destinations. Journal of Travel Research, 50(4), 431-442. https://doi.org/10.1177/0047287510368139

Denzin, N.K., \& Lincoln, Y.S. (2017). The SAGE handbook of qualitative research. USA, SAGE.

Dickson, P.H., Solomon, G.T., \& Weaver, K.M. (2008). Entrepreneurial selection and success: does education matter? Journal of small business and enterprise development, 15(2), 239-258. https://doi.org/10.1108/14626000810871655

Fernández, J.A.S., Azevedo, P.S., Martín, J.M.M., \& Martín, J.A.R. (2020). Determinants of tourism destination competitiveness in the countries most visited by international tourists: Proposal of a synthetic index. Tourism Management Perspectives, 33, 100582. https://doi.org/10.1016/j.tmp.2019.100582

Gannon, A. (1994). Rural tourism as a factor in rural community economic development for economies in transition. Journal of sustainable tourism, 2(1-2), 51-60. https://doi.org/10.1080/09669589409510683

Gao, J., \& Wu, B. (2017). Revitalizing traditional villages through rural tourism: A case study of Yuanjia Village, Shaanxi Province, China. Tourism Management, 63, 223-233. https://doi.org/10.1016/j.tourman.2017.04.003

Ghaderi, Z., \& Henderson, J.C. (2012). Sustainable rural tourism in Iran: A perspective from Hawraman Village. Tourism Management Perspectives, 2, 47-54. https://doi.org/10.1016/j.tmp.2012.03.001

Grilli, G., Tyllianakis, E., Luisetti, T., Ferrini, S., \& Turner, R.K. (2020). Prospective tourist preferences for sustainable tourism development in Small Island Developing States. Tourism Management, 82, 104-178. https://doi.org/10.1016/j.tourman.2020.104178

Hari Adi, P. \& Adawiyah, W.R. (2018). The impact of religiosity, environmental marketing orientation and practices on performance: A case of Muslim entrepreneurs in Indonesia, Journal of Islamic Marketing, 9(4), 841-862. https://doi.org/10.1108/JIMA-09-2016-0067

Honig, B. (2004). Entrepreneurship education: Toward a model of contingency-based business planning. Academy of Management Learning \& Education, 3(3), 258-273. https://doi.org/10.5465/amle.2004.14242112

Istiqomah, \& Adawiyah, W.R. (2018). Development of rural group entrepreneurship in Indonesia: benefits, problems, and challenges. International Journal of Entrepreneurship and Small Business, 34(3), 330-342. https://doi.org/10.1504/IJESB.2018.092748

López Salazar, A., Contreras Soto, R., \& Espinosa Mosqueda, R. (2011). The impact of financial decisions and strategy on small business competitiveness. Global Journal of Business Research, 6(2), 93-103.

Martín Martín, J.M., Salinas Fernández, J.A., Rodríguez Martín, J.A., \& Jiménez Aguilera, J.D.D. (2017). Assessment of the tourism's potential as a sustainable development instrument in terms of annual stability: Application to Spanish rural destinations in process of consolidation. Sustainability, 9(10), 1692. https://doi.org/10.3390/su9101692

Mazanec, J.A., \& Ring, A. (2011). Tourism destination competitiveness: second thoughts on the World Economic Forum reports. Tourism Economics, 17(4), 725-751. https://doi.org/10.5367/te.2011.0065

Mazanec, J.A., Wöber, K., \& Zins, A.H. (2007). Tourism destination competitiveness: from definition to explanation? Journal of Travel Research, 46(1), 8695. https://doi.org/10.1177/0047287507302389

Miles, M.B., Huberman, A.M., \& Saldaña, J. (2013). Qualitative data analysis: A methods sourcebook. Thousand Oaks, CA, Sage Publications.

Noe, R., Hollenbeck, J., Gerhart, B., \& Wright, P. (2006). Human Resources Management: Gaining a Competitive Advantage. Tenth Global Edition: McGraw-Hill Education.

Perales, R.M.Y. (2002). Rural tourism in Spain. Annals of Tourism Research, 29(4), 1101-1110. https://doi.org/10.1016/S0160-7383(02)00025-7

Pinasti, M., \& Adawiyah, W.R. (2016). Co-Opetition to Promote Growth of Batik Small and Medium Enterprises. International Journal of Business \& Society, 17(3). https://doi.org/10.33736/ijbs.532.2016

Pretorius, M., Nieman, G., \& Van Vuuren, J. (2005). Critical evaluation of two models for entrepreneurial education: An improved model through integration. International Journal of Educational Management, 19(5), 413-427. https://doi.org/10.1108/09513540510607743

Putri, N. K., Adawiyah, W. R., \& Pramuka, B. A. (2017). Independence of Audit Ethical Decision Making Process: A Case of Indonesia. DLSU Business \& Economics Review, 26(2), 1-1.

Sharpley, R., \& Roberts, L. (2004). Rural tourism-10 years on. International Journal of Tourism Research, 6(3), 119-124. https://doi.org/10.1002/jtr.478

Wihuda, F., Kurniawan, A.A., Kusumah, A.I., \& Adawiyah, W.R. (2017). Linking empowering leadership to employee service innovative behavior: A study from the hotel industry. Tourism: An International Interdisciplinary Journal, 65(3), 294-313. https://hrcak.srce.hr/187101

Yin, R.K. (2009). Case study research: Design and methods (4th Ed.). Thousand Oaks, CA, SAGE.

Article history: Received: $12.02 .2020 \quad$ Revised: 19.07 .2020
Accepted: 28.08.2020
Available online: 18.09.2020 